\section{Middelalders og nutids måneder}

\author{
Af forfatteren Per-Olof Johansson
}

I middelalderårets store maskineri er månedsbillederne at opfatte som et lille vigtigt tandhjul.

Kalendernes billeder for hver måned følger naturligt årstidernes vekslen, kunstens udvikling, historiens gang. De har også selv en historie.

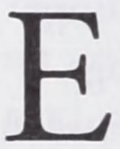

t forbindende tema i Nationalmuseets udstilling om middelalderen er årets gang, manifesteret ved tolv månedsbilleder fra en dansk billedkalender fra 1513, udlånt af Det Kongelige Bibliotek (Ny kgl. S. 901 12²).

På den plakat som bruges landet over for at gøre opmærksom på middelalderåret 1999 findes dette tema også repræsenteret, nemlig med en megastor gengivelse af et lille blybeslag med 6 månedsbilleder. Den farvestrålende plakat med Middelalder 99 i guld rummer der udover en hel række andre middelaldergenstande som ubesværet danner en sammenhæng for øjet, men som hver for sig kan give anledning til afhandlinger. Kalkmaleri fra Brunnby kirke i Skåne ca. 1500. En side fra håndskrift fra sent 1400-tal. Et knivskaft af ben, udskåret som falkoner, o. 1300. Og det pompøse Erik af Pommerens våbensegl fra 1398.

Guiden som samler en lang række af årets aktiviteter i anledning af middelalderåret landet over bruger pla- katen som forside, og har iøvrigt illustrationer fra håndskriftet der sammen med et kalkmaleri danner baggrund på plakaten.

Det er et håndskrift fra Det Kongelige biblioteks samlinger, en latinsk bønnebog som indgår i udstillingen Levende ord \& lysende billeder - en udstilling om den middelalderlige bogkultur i Danmark, som til begyndelsen af juni var at finde på Moesgård Museum og som fra indvielsen til efteråret vil være at finde på Det Kongelige Bibliotek. Overdådigt illustreret bl.a. med en fremstilling af de syv dødssynder. $\mathrm{Og}$ med en serie månedsbilleder hvoraf flere har fundet vej som vignetter i middelalderårets guide.

Månedsbilleder kender vi godt. Ved hvert årsskifte vælter vi os $i$ et broget udvalg af kalendere med et billede for hver måned. Vi køber dem eller vi får dem som gaver fra forretninger og firmaer. Det er en hel industri med mange facetter. Det er sin sag at afgøre hvad alt dette skal betyde i nutiden. Udbuddet af billedmuligheder er så enormt at enhver kan vælge noget der passer i eget kram.

Middelalderens billeder til illustration af måneden er, så underligt det end umiddelbart måtte lyde, et resultat af en bevidst ideologisk indsats fra kirkens side så langt tilbage som begyndelsen af 800-tallet. Illustrationerne viser gerne en beskæftigelse fra måneden og det lyder jo ikke særligt doktrinært. Så for at forstå at opfindelsen ikke var så enkel endda må vi bevæge os endnu et skridt længere tilbage, til førkristen tid i Rom.

Her kendte man nemlig også til illustrationer til månederne, hvormed der 
refereredes dels til de romerske guder, dels til årets fester. Disse billeder fortsatte deres liv ind i kristen tid og $\mathrm{i}$ forbindelse med hvad der kaldes billedstriden blev der også plads til at så tvivl om betimeligheden af at anvende de gamle romerske billeder. På billederne optrådte personificeringer af månederne, som måske kunne gøres til genstand for tilbedelse. Derfor optog man personifikationer som skulle fordømmes i et katalog, samtidig med at man proklamerede et kunstnerisk program for månedsbilleder. Hvert billede, hed det, skal indeholde en sandhed, dvs skal gengive virkeligheden. Billedet skal føre sindet fra løgnen til at dyrke sandheden. Det lykkedes ikke så godt for Karl den Store at ændre selve månedernes navne, men billedprogrammet må siges at være blevet en succes.

De høje mål med serierne gled måske i bagrunden, men udgangspunktet forblev synligt middelalderen igennem. Først med opkomsten af nye trykteknikker i 1800-tallets begyndelse kan programmet siges at være blevet et helt andet.

\section{To slags serier levede side om} side. En serietype med udgangspunkt i de kirkelige fester og en anden med udgangspunkt i årets arbejder - som jo også gav anledning til fejring, både ved begyndelse og ved afslutning. En overgang også en tredie type: Årets gang blev livets gang og ikke unaturligt kunne serierne så afspejle hele livsforløbet - gennemspillet på 12 måneder. Rester af sådanne serier med livsaldrerne ser vi, når det gamle år gengives som den gamle mand (et månedsbillede for december).
Og barnet (januar) som repræsentant for året der kommer.

Selvom billedernes indhold har haft en vis konstans, er der dog ikke tale om, at den enkelte serietypes billeder lå ganske fast. De lå end ikke fast på måned - det afhang af under hvilke himmelstrøg kalenderen var $\mathrm{i}$ anvendelse.

Det ser vi f.eks. i den lille blygenstand som er forstørret så stort på middelalder99-plakaten.

Månedsbillederne hørte altså ikke blot hjemme på pergament. De ældste finder vi i faste materialer - sten og mosaikker, fra kirkelige portaler og kirkestole til kalkmalerier, smykker og altså en dekoration som den på plakaten, beregnet som dette til at sætte på et lille skrin hvor man ser slagtning af et svin (december) og at olden slås ned til svinene (november), vi ser frugt eller druehøst (oktober), såning (september), tærskning (august) og hø-høst (juli).

Når beslaget, som er fundet ved en udgravning i Vimmelskaftet $32 \mathrm{i}$ København, vurderes som udenlandsk hænger det blandt andet sammen med den i forhold til danske omstændigheder forskudte aktivitet. I den kalender fra 1513 som følger os på Nationalmuseets udstilling tærskes der i september og sås i oktober, altså en måned senere.

Når man træder ind i Nationalmuseets udstilling er det første som møder en, en montre med kalendere og det lille blybeslag. Tænk at det er så lille - en diameter på $8 \mathrm{~cm}$ - når man har vænnet sig til plakatens næsten $40 \mathrm{~cm}$ ! Hvem ved, om man ellers overhovedet havde fået øjnene op for dets fortræffeligheder? Vi venter måske guld - men 


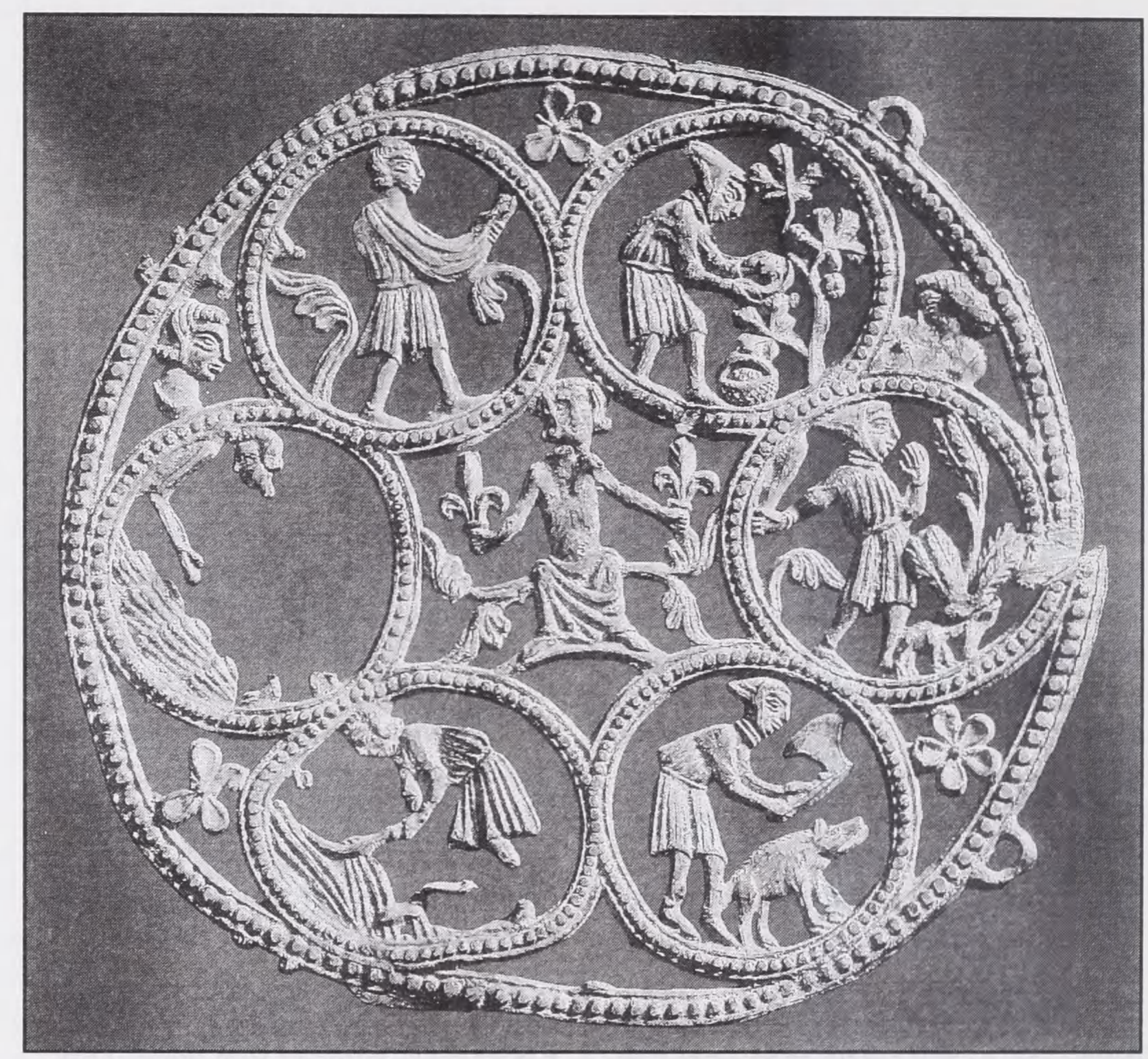

Bly-beslag til skrin, fundet Vimmelskaftet 32, Kobenhavn. Fra 0. 1300. Formentlig Spanien. Foto: Henrich Wichmann, Nationalmuseet.

det er af bly og det har ikke været et så uanseeligt materiale som idag. Vi er vænnet til respekt for bly som farligt for sundheden, den tid så noget helt andet $\mathrm{i}$ bly, derfor har der måske også ligget tanker bag, at det var af bly? Det blev i middelalderen ofte anvendt til masseproducerede smykker, pilgrimsmærker og lignende. Man tillagde bly mange egenskaber fra medicinske til magiske, hvilket kunne være et og det samme og derfor har det måske betydet noget, at sætte et blybeslag med månederne på sit skrin, var det en amulet?

Månedsbillederne var nok kommet til verden som et kristent ideologisk tiltag, siden indgik de i den sammenhængende verden som blev bundet sammen af astrologien. Man kan nok sige, at 1600-tallet var den periode, hvor månedsbilledernes tid i deres middelalderlige form løb ud. Dog var der en lille bog som hed Bonde-Practica som holdt dem i live ind i 1800-tallet. 
Bonde-Practica er er bog med broget indhold, en følgebog til almanakken med praktiske råd om åreladningen og spådomsvers måned for måned om livets gang og om hvordan man skulle leve. Oplag efter oplag bar de samme billeder videre - herunder en månedsbilledserie som først kendes i tryk fra begyndelsen af 1500-tallet. Bevares, langt fra den pragt som de udførtes med i middelalderens håndskrifter, men motiverne overlevede.

Den kalender, hvis billeder følger os igennem Nationalmuseets temaer og hvis billeder ses på plakaten for Nationalmuseet, var i sin grund en evighedskalender, kunne bruges år efter år.

Bonde-Practica blev til da man begyndte med trykte almanakker år for år. Bragte tekster som tidligere indgik i diverse trykte evighedskalendere, efterfølgerne til de håndskrevne billedkalendere, hvad enten de var store eller små. Så her ser vi den sammenhæng månedsbillederne indgik $\mathrm{i}$ - hele det middelalderlige astrologiske verdensbillede.

Derfor får vi også de syv planeter og hvilke indvirkninger de har på menneskelivet. Saturn, som repræsenterer bly, siger f.eks. at han er gammel, kold og uden skæmt, hadsk og glemmer al forsigtighed. Hans børn er fulde af nid og had, "metal og blye min handel mon være”. Er man født i Stenbukkens tegn er man af Saturns natur, sangvinsk, hed og våd. Altså har det kunnet betyde lidt af hvert, må man tro, at sætte hans metal bly på sit skrin! En "planetbog" siger Saturn er påholdende, en anden at i hans time er det godt at sælge og købe allehånde vægtige ting, især alle metaller.

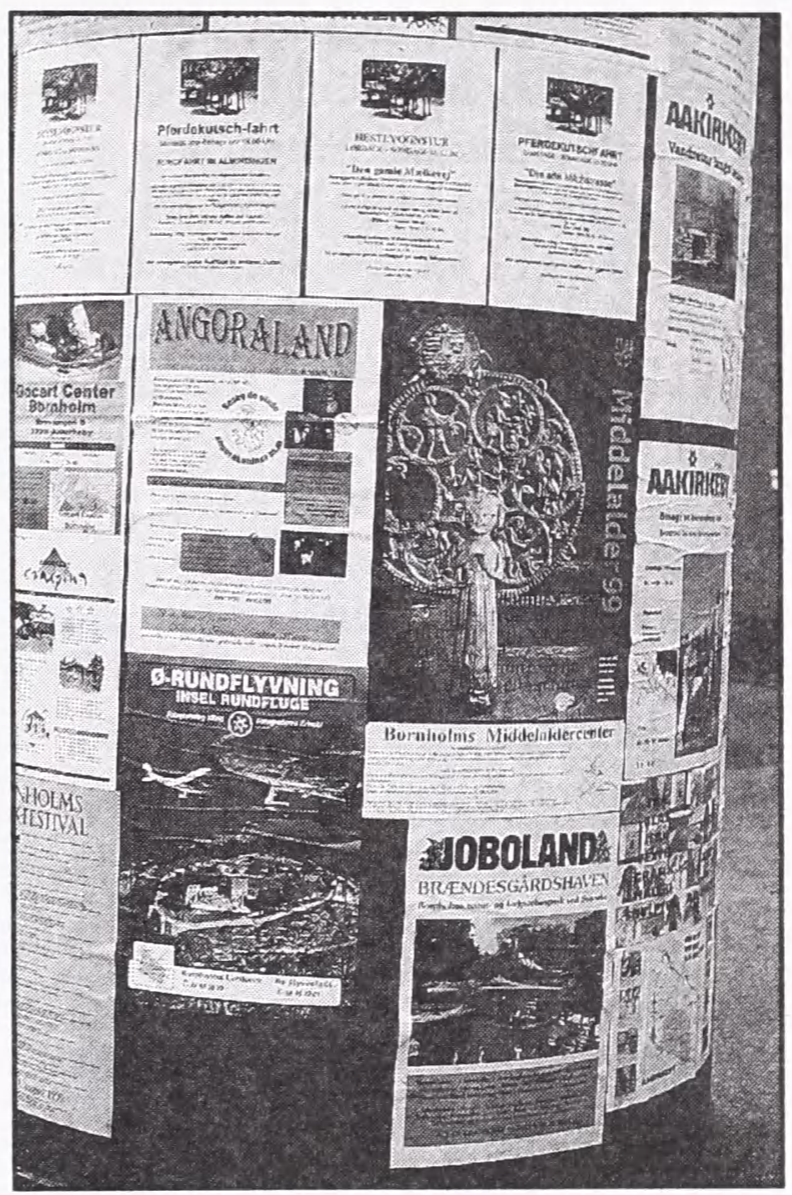

Plakatsojle, Bodernne Vandrehjem, Bornholm. Foto: poj.

Et bevaret smykkeskrin har hele fem lignende helt ens beslag, med næsten identiske billeder for årets sidste seks måneder - de måneder som samlet kan siges at repræsentere høsten. Det ligner en besværgelse. Den tronende midterfigur med en lilje $\mathrm{i}$ hver hånd - som den lykkelige ejermand af høstens rigdomme.

Månedsbillederne kender vi som sagt $\mathrm{i}$ nutiden - og ikke sjældent i den samme dragt som tidligere. At repræsentere august med høst forstår enhver, selvom historien om, hvordan det blev "månedsbillede" ikke er present.

Det er faktisk sådan, at samt- 
lige de månedsbilledmotiver, som findes i Bonde-Practica løb over i en så speciel tryksag som frimærker! Enten som gengivelse af de historiske billeder eller de gamle motiver i nye versioner. Så forsvinder "månedstemaet" måske tit også, men brugen vidner om, at fascinationen af motiverne lever den dag i dag.

Guden Janus var i Rom gud for året - med sit dobbelte ansigt, som ser frem og tilbage. Han blev i sit tempel i Rom tilbedt af månederne - billeder som stod rundt om hans skulptur. Som parallel hertil digtede den kristne digter Ephraem Syrer i 300-tallet om måne-

Litteratur

Arvidsson, Bengt: Bildstrid Bildbruk Bildlära. Studia Theologica Lundensia nr. 41. Lund 1987.

Børthy, Lissa: Billedkalender fra 1513. I: Almanak. Kulturhistorisk Tidsskrift nr. 6. Tønder 1967.

Børthy, Lissa: En dansk billedkalender fra 1513. I: Folkeminder, 12. heft. Kbh. 1966.

Dal, Erik and Povl Skaarup: The Ages of Man and the Months of the Year.Kbh. 1980.

Dal, Erik (udg.): Niels Helvad: En smuk ihukommelse om menneskets alder efter de 12 måneder $i$ året afdelt. Odense 1960.

Damsgaard, Helle (red) Nationalmuseet nyt, nr. 83. København 1999.

Den aldgamle ubedragelig Plantebog, hvori De syv Planeter etc. København u.å.

Dumreicher, Carl og Sofus Larsen: Et blokbogsfund i Danmark. Aarhus 1929.

Granlund, John: Medeltida månadsbilder. I: Saga och sed. Kungl. Gustav Adolfs Akademiens Arsbok 1964.

Johansson, Per-Olof: Bonde-Practica eller VeyrBog. Bd. 1: Udvalg, omtale, bibliografi, litteratur. Bd. 2: Faks. af udgave 1744 [Kbh. 1976].

Liebgott, Niels-Knud: Dansk Billedkalender på derne, som tilbad Jesus.

I dag er dyrkelsen af månederne mere intensiv end nogensinde før i historien - skønt dyrkelsen er uden navn og vi frakender den religiøst indhold: den er alene praktisk og nødvendig. Og dog: vis mig dine månedsbilleder og jeg skal sige dig hvem du er. I år burde jeg bestemt have haft en kalender med middelalderlige månedsbilleder og ikke den rædselsfulde fra "Løvbjerg FOOD MART" hvor månedsbilledet for juli er 'revelsben på grill med kartoffel-spinatsalat og jolly sauce'.

Noget af et fald fra et enkelt billede med høhøsten.

pergament 1513. Udklipsark med tekst.

Nationalmuseet. U.å. [1974?]

Margrethe 1. Nordens Frue og Husbond. Kalmarunionen 600 ar. Essays og Udstillingskatalog. Trelleborg 1996. Kat. nr. 45.

Nørlund, Poul: Et jordfund fra Vimmelskaftet. I: Smaastudier tilegnet Christian Axel Jensen på hans 65 Aars Fodselsdag. Kbh. 1943.

Olesen, Dorthe Hove og Anette Lerche Trolle (red): Guide til Middelalderårets arrangementer. Kerteminde 1999.

Petersen, Erik: Levende ord \& lysende billeder. Den middelalderlige bogkultur i Danmark. Katalog. Kbh.1999. Kat. nr. 142.

Rugaard, D.E.: Aaret og dets Maaneder. Kjøbenhavn 1863.

Rørdam, T. Skat (overs.): Aandelige Digte of Afrem Syrer. Kjøbenhavn 1879.

Webster, James Carson: The Labors of the Months in Antique and Mediaeval Art. I: Northwestern University Studies in the Humanities Number Four 1938. New York 1970.

2 plakater for Nationalmuseet 1999 med billeder fra kalender 1513, hhv. 1. og 2. halvår. Plakaten viser for 2 . halvår april-billedet $\mathrm{i}$ stedet for december-billedet. 